Jurnal Riset Agama

Volume 1, Nomor 1 (April 2021): 209-222

https://journal.uinsgd.ac.id/index.php/jra

\title{
Susu Steril Kurma Minuman Sehat untuk Masa Pandemi Covid-19: Studi Takhrij dan Syarah Hadis Pendekatan Bidang Kesehatan
}

\author{
Asti Sovie Fuziawatie \\ Jurusan Ilmu Al-Qur'an dan Tafsir, Fakultas Ushuluddin \\ UIN Sunan Gunung Djati Bandung, Indonesia \\ astisovief02@gmail.com
}

\begin{abstract}
The purpose of this study is to discuss the hadith syarah related to sterile date milk as a healthy drink during the Covid-19 pandemic. This study uses a qualitative approach that emphasizes literature study through the takhrij and syarah hadith methods with contemporary analysis. The results of this study found that the quality status of the hadith about dates is considered valid according to the takhrij hadith. Meanwhile, the hadith syarah shows that dates are known to be processed ingredients for health drinks, including sterile date milk which is useful for increasing immunity during the Covid-19 pandemic. The conclusion of this study is that the hadith about dates can be referred to as an Islamic practice because it has a valid status and dates can be used as sterile date milk products to increase immunity during the Covid-19 pandemic according to health sector instructions. This study recommends the collaboration of hadith experts and health experts in experimental processing of sterile dates milk for health during the Covid-19 period.
\end{abstract}

Key words: Covid-19; Dates; Hadith; Milk

\begin{abstract}
Abstrak
Tujuan penelitian ini yaitu membahas syarah hadis terkait susu steril kurma sebagai minuman sehat di masa pandemi Covid-19. Penelitian ini menggunakan pendekatan kualitatif yang ditekankan pada studi pustaka melalui metode takhrij dan syarah hadis dengan analisis kontemporer. Hasil penelitian ini menemukan bahwa status kualitas hadis tentang buah kurma dinilai sahih menurut takhrij hadis. Sedangkan syarah hadis menunjukkan bahwa buah kurma diketahui sebagai bahan olahan minuman kesehatan mencakup susu steril kurma yang bermanfaat untuk meningkatkan imun di masa pandemi Covid19. Kesimpulan penelitian ini adalah hadis tentang buah kurma dapat
\end{abstract}


Jurnal Riset Agama, Volume 1, Nomor 1 (April 2021): 209-222

Asti Sovie Fuziawatie/Susu Steril Kurma Minuman Sehat untuk Masa Pandemi

Covid-19: Studi Takhrij dan Syarah Hadis Pendekatan Bidang Kesehatan

dirujuk menjadi amalan Islam karena memiliki status sahih dan buah kurma dapat dimanfaatkan sebagai olahan susu steril kurma untuk meningkatkan imun di masa pandemi Covid-19 sesuai petunjuk bidang kesehatan. Penelitian ini merekomendasikan kolaboarasi ahli hadis dan ahli kesehatan dalam eksperimen pengolahan susu steril kurma bagi kesehatan di masa Covid-19.

Kata Kunci: Covid-19; Hadis; Kurma; Susu

\section{Pendahuluan}

Kurma mendapat posisi istimewa di hati para muslimin. Kurma dianggap sebagai makanan yang baik juga dinasihatkan dan dijelaskan oleh Nabi Muhammad SAW dalam banyak Hadis, Nabi Muhammad SAW menobatkan buah kurma sebagai makanan pembuka puasa dan makanan yang bayak khasiatnyanya (Satuha, 2014). Kurma merupakan buah yang tinggi nilai gizinya dan amat sesuai dengan tubuh badan manusia yang diciptakan Allah SWT. Manfaat dan khasiat kurma ditinjau dari sudut pandang medis menguatkan khabar Al-Qur'an Al-Karim dan Al-Sunnah Al-Shahihah tentang khasiat dan keutamaan kurma. Berikut manfaat kurma yang berfungsi untuk menguatkan sel-sel usus dan dapat membantu melancarkan saluran kencing karena mengandung serabut-serabut yang bertugas mengontrol laju gerak usus dan menguatkan rahim terutama ketika melahirkan. Ternyata hampir semua dari kurma boleh diambil manfaat bermula dari pangkal hingga batang. Kurma dapat menjadi obat untuk berbagai penyakit karena nilai gizi, mineral, zat besi dan lain-lain yang terdapat di dalamnya merangkumi semua kebutuhan badan. Kemukjizatan Al-Qur'an yang menerangkan kepada kita akan betapa baiknya kurma itu sesuai dengan kandungan yang diperolehi darinya (Syamil, 2013). Kemudian susu merupakan produk yang dihasilkan asal ternak yang memiliki fungsi sebagai sumber energi untuk metabolisme tubuh karena memiliki gizi lengkap seperti karbohidrat, protein, lemak, vitamin, dan mineral. Susu memiliki zat antibodi seperti imunoglobulin yang bagus untuk pertumbuhan anak (Saleh, 2004). Namun mengkonsumsi susu di Indonesia juga masih dalam kondisi yang minim yaitu 16,53 liter per kapita per tahun dibandingkan dengan sejumlah negara yang berada di wilayah ASEAN, tentu hal ini menjadi tantangan bagi pemerintah khsususnya instansi yang terkait untuk mengatasi permasalahan tersebut (Christi et al., 2019). Oleh karena itu, terlebih sekarang ini masih dalam keadaan Covid, tentunya perpaduan antara kurma dan susu merupakan hal yang sangat baik bagi 
Jurnal Riset Agama, Volume 1, Nomor 1 (April 2021): 209-222

Asti Sovie Fuziawatie/Susu Steril Kurma Minuman Sehat untuk Masa Pandemi

Covid-19: Studi Takhrij dan Syarah Hadis Pendekatan Bidang Kesehatan

kesehatan tubuh kita. Semakin banyak manfaat yang akan didapatkan dari keduanya.

Beberapa pakar sudah melakukan penelitian sebagaimana telah ditinjaua dalam pustaka ini, seperti Syamil (2013), "Keistimewaan buah kurma dalam Al-Qur'an dari segi kesehatan," Universitas Islam Negeri Sultan Syarif Kasim Riau. Penelitian berikut memakai teori tafsir yang termasuk ke dalam jenis penelitian kualitatif menggunakan ancangan atau pendekatan tafsir maudu'i. Kesimpulan dari pembahasan penelitian ini ialah begitu istimewanya buah kurma ini dari buah lainnya. Penelitian ini memprediksikan kesimpulan bahwa banyak sekali keistimewaan yang dimiliki buah kurma (Syamil, 2013). Zulfadli (2015), “Kurma dalam Al-Qur'an (Kajian Tahlili Terhadap Q.S Maryam [19] : 25-26)," Universitas Islam Negeri Alauddin Makassar. Penelitian ini menggunakan teori kesehatan Islam yang merupakan jenis penelitian kualitatif dengan pendekatan Qurani, ilmu kesehatan, dan teologis. Hasil dari pembahasan penelitian ini adalah dengan menunjukan bahwa kurma termaktub dalam (QS. Maryam [19]: 25-26) merupakan kurma untuk Maryam As., yang memiliki banyak kandungan nutrisi dan bermanfaat sebagai obat. Penelitian ini memprediksikan kesimpulan bahwa kurma di dalam Al-Qur'an terdapat banyak manfaat dan dari ayat di atas merupakan kurma untuk Maryam As (Zulfadli, 2015). Satuha (2014), "Syarah dan Kritik dengan Metode Takhrij Hadis tentang Kurma Ajwa dan Implikasinya terhadap Kesehatan," UIN Sunan Gunung Djati Bandung, Indonesia. Penelitian ini memakai teori kehujahan hadis dengan jenis penelitian kualitatif menggunakan pendekatan syarah dan takhrij. Dari pembahasan penelitian ini dapat diambil kesimpulan bahwa kurma ajwa bisa disebut sebagai kurma Nabi Saw. atau kurma Rasullullah Saw. Yang mana kurma ajwa ini ditanam langsung oleh Nabi Muhammad SAW di Kota Madinah diperkirakan 14 abad lalu dan juga mengetahui akan kehujahan hadisnya. Penelitian ini memprediksikan kesimpulan bahwa kurma Ajwa disebut kurma Nabi (Satuha, 2014).

Penelitian sebelumnya mengenai susu steril minuman kurma yang telah diuraikan pada tinjauan pustaka sangat berkontribusi terhadap penyusunan kerangkka berpikir ini. Masyarakat dunia dihebohkan dengan adanya virus corona pada bulan Desember 2019. Mulanya kejadian ini terjadi di Wuhan, Tiongkok (Yuliana, 2020). Munculnya virus corona telah menarik perhatian global. Peningkatan jumlah kasus yang meningkat dalam waktu yang cepat menyebabkan Covid-19 menjadi pandemi. Sars-CoV-2 merupakan virus penyebab Covid-19. Virus corona merupakan zoonosis (ditularkan antara hewan dan manusia). Penelitian menujukkan bahwa percikan batuk atau 
Jurnal Riset Agama, Volume 1, Nomor 1 (April 2021): 209-222

Asti Sovie Fuziawatie/Susu Steril Kurma Minuman Sehat untuk Masa Pandemi

Covid-19: Studi Takhrij dan Syarah Hadis Pendekatan Bidang Kesehatan

bersin (droplet) merupakan cara penularan Covid-19 dari manusia ke manusia melalui udara. Ketika droplet terhirup dekat dengan orang yang tidak terinfeksi Covid-19 lewat mulut atau hidung (Irmayani et al., 2021). Strategi penanggulangan wabah juga dilakukan oleh Nabi Shallallahu 'alaihi wasallam yang ditinjau dari Kitab Hadis Shahih Bukhari dapat disimpulkan menjadi poin yaitu : Wajib menghindari atau isolasi diri. Isolasi mandiri yakni tetap di wilayah terdampak, yang mana tidak membahayakan orang sekitar dan diri sendiri. Tetap optimis dan berprasangka baik pada Allah SWT. Bertaubat dengan memohon lindungan kepada Allah SWT (Artha, 2021). Zat gizi yang terdapat dalam susu sapi membuat susu memiliki banyak khasiat bagi tubuh, antara lain untuk pertumbuhan, pemelihara kesehatan, dan kecerdasan. Susu sapi merupakan sumber protein hewani yang banyak sekali khasiatnya, dan sebagai bahan pangan yang kaya akan kandungan berbagai zat gizi (Fida, 2017). Susu mempunyai kandungan nutrisi yang baik daripada minuman lain sehingga susu memiliki banyak manfaat bagi kesehatan tubuh. Terdapat kandungan nutrisi di dalam susu seperti: zinc, fosfor, kalsium, vitamin A, vitamin B12, vitamin B12, vitamin D, dan asam amino. Kandungan gizi ini bermanfaat bagi kesehatan imun terutama gigi dan tulang (Wardyaningrum, 2011). Kurma merupakan buah yang mengandung banyak khasiat atau manfaat. Batang pohonnya bisa digunakan untuk menghangatkan badan jika dibakar, lalu dapat pula diolah sebagai peralatan rumah seperti: kursi kayu, meja kayu. Begitu pula dengan buahnya yang bisa dimanfaatkan sebagai obat. Kurma mengandung banyak keistimewaan. Adapun kandungan gizi dalam buah kurma seperti: kalsium, protein, mineral, zat besi, lemak, kalori, vitamin (Zulfadli, 2015).

Berdasarkan pada pemaparan tersebut, formula penelitian yang disusun seperti: rumusan masalah penelitian, pertanyaan utama penelitian, dan tujuan penelitian (Darmalaksana, 2020a). Rumusan masalah terhadap penelitian ini ialah terdapat syarah hadis tentang susu steril kurma minuman sehat di masa pandemi Covid-19. Pertanyaan utama penelitian ini ialah bagaimana syarah hadis tentang susu steril kurma minuman sehat di masa pandemi Covid-19. Sedangkan pertanyaan penelitian secara terperinci yakni bagaimana teks hadis tentang kurma, bagaimana kualitas hadis tentang kurma, bagaimana syarah hadis tentang susu steril kurma minuman sehat di masa pandemi Covid-19. Tujuan penelitian ini yaitu membahas syarah hadis tentang susu steril kurma minuman sehat di masa pandemi Covid-19. Penelitian ini diharapkan bermanfaat bagi masyarakat yang ingin mengetahui tentang susu steril kurma minuman sehat di masa pandemi Covid-19. 
Jurnal Riset Agama, Volume 1, Nomor 1 (April 2021): 209-222

Asti Sovie Fuziawatie/Susu Steril Kurma Minuman Sehat untuk Masa Pandemi

Covid-19: Studi Takhrij dan Syarah Hadis Pendekatan Bidang Kesehatan

\section{Metode Penelitian}

Penelitian ini meggunakan jenis kualitatif melalui studi pustaka (Darmalaksana, 2020b). Pada penelitan ini metode yang digunakan adalah dengan menerapkan metode takhrij dan syarah (Darmalaksana, 2020d) terhadap hadits yang berkenaan dengan susu kurma melalui analisis kontemporer (Darmalaksana, 2020c), khususnya bidang kesehatan.

\section{Hasil dan Pembahasan Penelitian}

Hasil penelitian dan pembahasan disajikan dalam beberapa hal.

\section{Teks Hadis Kurma}

Berdasarkan pencarian hadis tentang kurma melalui aplikasi Ensiklopedia Hadis Kitab 9 Imam (Saltanera, 2015), penulis mendapati beberapa hadis, akan tetapi hadis yang akan menjadi pembahasan utama dalam penelitian ini adalah hadis riwayat Muslim No. 3812 Kitab Minuman Bab Menyimpan Kurma dan makanan pokok lainnya untuk keluarga, sebagai berikut.

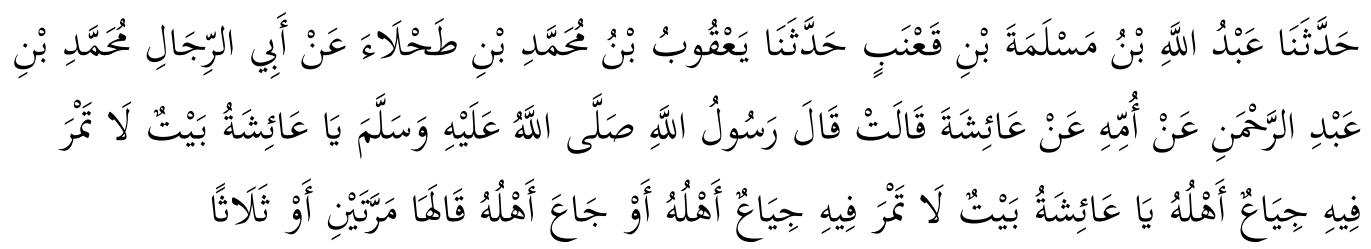

Artinya: Telah menceritakan kepada kami Abdullah bin Maslamah bin Qa'nabi, Telah menceritakan kepada kami Ya'qub bin Muhammad bin Thahlaa' dari Abu Rijal Muhammad bin Abdurrahman dari Ibunya dari 'Aisyah dia berkata; Rasulullah bersabda, "Wahai 'Aisyah! Rumah yang di dalamnya tidak ada kurma, maka penghuninya akan lapar, Wahai 'Aisyah! Rumah yang di dalamnya tidak ada kurma, maka penghuninya akan lapar." Beliau mengucapkannya sebanyak dua atau tiga kali (HR. Muslim).

\section{Takhrij Hadis tentang Buah Kurma}

Takhrij hadis terkait buah kurma ditampilkan dalam bentuk tabel berikut. 
Jurnal Riset Agama, Volume 1, Nomor 1 (April 2021): 209-222

Asti Sovie Fuziawatie/Susu Steril Kurma Minuman Sehat untuk Masa Pandemi

Covid-19: Studi Takhrij dan Syarah Hadis Pendekatan Bidang Kesehatan

Tabel 1. Daftar Rawi Sanad

\begin{tabular}{|c|c|c|c|c|c|c|c|c|}
\hline \multirow[t]{2}{*}{ No. } & \multirow{2}{*}{$\begin{array}{l}\text { Rawi } \\
\text { Sanad }\end{array}$} & \multicolumn{2}{|c|}{$\begin{array}{l}\text { Lahir/ } \\
\text { Wafat }\end{array}$} & \multirow[t]{2}{*}{ Negeri } & \multirow[t]{2}{*}{ Kuniyah } & \multicolumn{2}{|c|}{$\begin{array}{c}\text { Komentar } \\
\text { Ulama }\end{array}$} & \multirow[t]{2}{*}{ Kalangan } \\
\hline & & L & W & & & - & + & \\
\hline 1 & $\begin{array}{l}\text { Aisyah } \\
\text { binti Abi } \\
\text { Bakar } \\
\text { Ash } \\
\text { Shiddiq }\end{array}$ & & $58 \mathrm{H}$ & Madinah & $\begin{array}{l}\text { Ummu } \\
\text { 'Abdullah }\end{array}$ & & & Shahabat \\
\hline 2 & $\begin{array}{l}\text { Amrah } \\
\text { binti } \\
\text { 'Abdur } \\
\text { Rahman } \\
\text { bin Sa'ad } \\
\text { bin } \\
\text { Zurarah }\end{array}$ & & & Madinah & & & $\begin{array}{l}\text { Yahya bin } \\
\text { Ma'in: } \\
\text { Tsiqah; } \\
\text { Al- 'Ajli: } \\
\text { Tsiqah; } \\
\text { Ibnu } \\
\text { Hibban: } \\
\text { 'ats } \\
\text { tsiqaat; } \\
\text { Ibnu } \\
\text { Hajar al- } \\
\text { 'Asqalani: } \\
\text { Tsiqah; } \\
\text { Adz- } \\
\text { Dzahabi: } \\
\text { Ahli Fiqih } \\
\text { Tabi' in }\end{array}$ & $\begin{array}{l}\text { Tabi'in } \\
\text { kalangan } \\
\text { pertengahan }\end{array}$ \\
\hline 3 & $\begin{array}{l}\text { Muhamm } \\
\text { ad bin } \\
\text { 'Abdur } \\
\text { Rahman } \\
\text { bin } \\
\text { Haritsah }\end{array}$ & & & Madinah & $\begin{array}{l}\text { Abu } \\
\text { 'Abdur } \\
\text { Rahman }\end{array}$ & & $\begin{array}{l}\text { Muhamm } \\
\text { ad bin } \\
\text { Sa'ad: } \\
\text { Tsiqah; } \\
\text { Abu } \\
\text { Daud: } \\
\text { Tsiqah; } \\
\text { An- } \\
\text { Nasa'i: } \\
\text { Tsiqah; } \\
\text { Ibnu } \\
\text { Hibban: } \\
\text { Disebutka } \\
\text { n dalam } \\
\text { 'ats } \\
\text { tsiqaat; } \\
\text { Al- } \\
\text { Bukhari: } \\
\text { Tsabat; }\end{array}$ & $\begin{array}{l}\text { Tabi'in } \\
\text { kalangan } \\
\text { pertengahan }\end{array}$ \\
\hline
\end{tabular}


Jurnal Riset Agama, Volume 1, Nomor 1 (April 2021): 209-222

Asti Sovie Fuziawatie/Susu Steril Kurma Minuman Sehat untuk Masa Pandemi Covid-19: Studi Takhrij dan Syarah Hadis Pendekatan Bidang Kesehatan

\begin{tabular}{|c|c|c|c|c|c|c|}
\hline & $\begin{array}{l}\text { bin An } \\
N^{\prime} \text { man }\end{array}$ & & & & $\begin{array}{l}\text { Yahya bin } \\
\text { Ma'in: } \\
\text { Tsiqah; } \\
\text { Ahmad } \\
\text { bin } \\
\text { Hambal: } \\
\text { Tsiqah; } \\
\text { Abu } \\
\text { Hatim: } \\
\text { Tsiqah; } \\
\text { Ibnu } \\
\text { Hajar al- } \\
\text { 'Asqalani: } \\
\text { Tsiqah }\end{array}$ & \\
\hline 4 & $\begin{array}{l}\text { Ya'qub } \\
\text { bin } \\
\text { Muhamm } \\
\text { ad bin } \\
\text { Thahla' }\end{array}$ & $162 \mathrm{H}$ & Madinah & $\begin{array}{l}\text { Abu } \\
\text { Yusuf }\end{array}$ & $\begin{array}{l}\text { Ahmad } \\
\text { bin } \\
\text { Hambal: } \\
\text { Tsiqah; } \\
\text { An- } \\
\text { Nasa'i: } \\
\text { Tsiqah; } \\
\text { Yahya bin } \\
\text { Ma'in: } \\
\text { Tsiqah; } \\
\text { Abu } \\
\text { Daud: La } \\
\text { ba'sa bih; } \\
\text { Abu } \\
\text { Hatim: La } \\
\text { ba'sa bih; } \\
\text { Ibnu } \\
\text { Hibban: } \\
\text { Disebutka } \\
\text { n dalam } \\
\text { 'ats } \\
\text { tsiqaat; } \\
\text { Ibnu } \\
\text { Hajar al- } \\
\text { 'Asqalani: } \\
\text { Laisa bihi } \\
\text { ba's; Adz } \\
\text { Dzahabi: } \\
\text { Tsiqah }\end{array}$ & $\begin{array}{l}\text { Tabi'ut } \\
\text { Tabi'in } \\
\text { kalangan tua }\end{array}$ \\
\hline & $\begin{array}{l}\text { Abdullah } \\
\text { bin } \\
\text { Maslama }\end{array}$ & & & & $\begin{array}{l}\text { Ibnu } \\
\text { Hibban: } \\
\text { Disebutka } \\
\text { n dalam }\end{array}$ & \\
\hline
\end{tabular}


Jurnal Riset Agama, Volume 1, Nomor 1 (April 2021): 209-222

Asti Sovie Fuziawatie/Susu Steril Kurma Minuman Sehat untuk Masa Pandemi Covid-19: Studi Takhrij dan Syarah Hadis Pendekatan Bidang Kesehatan

\begin{tabular}{|c|c|c|c|c|c|c|c|}
\hline 5 & $\begin{array}{l}\mathrm{h} \text { bin } \\
\text { Qa'nab }\end{array}$ & & $221 \mathrm{H}$ & Madinah & $\begin{array}{l}\text { Abu } \\
\text { 'Abdur } \\
\text { Rahman }\end{array}$ & $\begin{array}{l}\text { 'ats } \\
\text { tsiqaat; } \\
\text { Ibnu } \\
\text { Hajar: } \\
\text { Tsiqah } \\
\text { ahli } \\
\text { ibadah; } \\
\text { Abu } \\
\text { Hatim: } \\
\text { Tsiqah } \\
\text { hujjah }\end{array}$ & $\begin{array}{l}\text { Tabi'ut } \\
\text { Tabi'in } \\
\text { kalangan } \\
\text { biasa }\end{array}$ \\
\hline 6 & $\begin{array}{l}\text { Al-Imam } \\
\text { Abul } \\
\text { Husain } \\
\text { Muslim } \\
\text { bin al- } \\
\text { Hajjaj al- } \\
\text { Qusyairi } \\
\text { an- } \\
\text { Naisaburi }\end{array}$ & $204 \mathrm{H}$ & $261 \mathrm{H}$ & Iran & & $\begin{array}{l}\text { Imam } \\
\text { Hadis }\end{array}$ & Mudawwin \\
\hline
\end{tabular}

Tabel 1 merupakan daftar rawi dan sanad hadis riwayat Imam Muslim No. 3812 Kitab Minuman Bab Menyimpan Kurma dan makanan pokok lainnya untuk keluarga. Pada tabel tersebut terdapat matrik rawi-sanad, tahun lahir dan wafat, negeri, kuniyah (panggilan), komentar ulama, dan disebutkan pula kalangannya. Hadis ini diriwayatkan oleh 6 (enam) orang rawi mulai dari mukharrij sampai mudawwin. Hanya 1 (satu) orang rawi yang diketahui tahun lahirnya, yaitu Al-Imam Abdul Husain. Sebanyak 2 (dua) orang rawi yang tidak diketahui kuniyahnya, yaitu Amran binti 'Abdur Rahman dan AlImam Abdul Husain. Rawi pertama hadis ini ialah Aisyah binti Abi Bakar Ash Shiddiq. Sedangkan sanad pertama dari hadis ini ialah Al-Iman Abdul Husain. Berdasarkan Ilmu Hadis rawi pertama merupakan sanad terakhir sedangkan rawi terakhir merupakan sanad pertama (Darmalaksana, 2021b).

\section{Kualitas Hadis tentang Buah Kurma}

Hadis dikatakan sahih apabila rawinya adil dan kuat hafalannya (dhabit), matan hadis tidak janggal (syadz), sanadnya harus bersambung (muttasil), dan matan hadis tidak cacat (Darmalaksana, 2018). Pada tabel 1 tampak banyak para ulama yang memberi komentar positif terhadap para rawi dengan memberi komentar tsiqah. Tsiqah ialah gabungan gabungan dari dhabit dan adil (Nadhiran, 2014). Komentar ulama sangat beragam cakupannya ada penilaian positif ( $\left.t a^{\prime} d i l\right)$ dan penilaian negatif (jarh) (Darmalaksana, 2021b). 
Jurnal Riset Agama, Volume 1, Nomor 1 (April 2021): 209-222

Asti Sovie Fuziawatie/Susu Steril Kurma Minuman Sehat untuk Masa Pandemi

Covid-19: Studi Takhrij dan Syarah Hadis Pendekatan Bidang Kesehatan

Rawi yang dinilai tsiqah berarti ia merupakan orang yang adil dan kuat hafalannya. Selain tsiqah para ulama juga memberikan komentar ahli fiqih tabi'in, disebutkan dalam 'ats tsiqaat, tsabat, laisa bihi ba's dan la ba'sa bih. Kemudian tidak terdapat komentar yang negatif pada tabel 1 terhadap para rawi. Dengan ini bisa disimpulkan bahwa rawi dalam jalur sanad ini seluruhnya adil dan kuat hafalannya sehingga dapat mempengaruhi kualitas hadis. Kemudian syarat sanad bersambung adalah liqa' (bertemu) antara guru (yang menyampaikan hadis) dan murid (yang menerima hadis) (Darmalaksana, 2018). Antara guru dan murid dapat dikatakan bertemu apabila mereka sezaman atau berada pada satu wilayah, yang mana itu dapat dilihat dari tahun lahir dan wafat para periwayat (Darmalaksana, 2020d).

Apabila tahun lahir dan wafat para periwayat tidak diketahui, maka para rawi dapat diasumsikan rata-rata berusia kurang lebih 90 tahun (Darmalaksana, 2021a). Oleh karena itu, walaupun pada Tabel 1 beberapa rawi tidak diketahui tahun lahir dan wafatnya, maka para rawi diperkirakan bertemu antara guru dan murid. Dengan kata lain, sanad hadis pada Tabel 1 dapat dikatakan bersambung (muttasil) (Firdaus, 2015).

Selain penilaian dari seri rawi dan sanad, kualitas hadis ditentukan dari segi matan dengan syarat terhindar dari kejanggalan dan cacat (Siti Rohmaturrosyidah Ratnawati \& Ali Yasmanto, 2019). Karena dalam hadis yang dibahas ini tidak terdapat kejanggalan dan cacat, maka dari itu dapat disimpulkan bahwa hadis riwayat Imam Muslim No. 3812 dapat diterima sebagai hadis shahih.

Hadits mengenai buah kurma ini selain bernilai shahih juga memberi petunjuk bahwa kurma merupakan makanan yang layak dikonsumsi. Dari sanad ke-1 hingga sanad ke-6 atau mukharrij, ialah bersambung. Maksudnya, mereka sama dipercaya menerima hadits tentang kurma dari Nabi SAW. Dari adanya persambungan ini jelas bahwa hadits tersebut dilihat dari kualitas sanad ialah bernilai shahih. Sedangkan dari sudut matan hadits, hadits di atas tidak ada yang bertentangan dengan tolok ukur keshahihan matan. Menurut al-Adhlabi, tolok ukur untuk penelitian matan (ma'ayir naqd al-matan) ada empat atau lima macam yakni tidak bertentangan akan akal sehat dan indera, dengan yang lebih kuat hadisnya, dengan al-Qur'an, tidak berkesinambungan dengan masa lampau atau sejarah, dan pernyataan yang menunjukkan ciri dari sabda kenabian. Oleh karena itu, hadits tersebut, selain shahih sanad juga matan. Pendek kata, hadits tentang kurma adalah shahih sanad dan shahih matan. Dengan ungkapan lain, hadits itu dalam keutuhannya dapat dijadikan hujah tentang buah kurma (Satuha, 2014) dan stoknya sebagai makanan seharihari dalam keluarga perlu tersedia secara cukup. Artinya, buah kurma 
Jurnal Riset Agama, Volume 1, Nomor 1 (April 2021): 209-222

Asti Sovie Fuziawatie/Susu Steril Kurma Minuman Sehat untuk Masa Pandemi

Covid-19: Studi Takhrij dan Syarah Hadis Pendekatan Bidang Kesehatan

merupakan makanan yang bermanfaat bagi kesehatan sehingga bisa dikonsumsi memenuhi kebutuhan hidup sehari-hari. Dalam konteks Indonesia, kurma bagi pengkonsumsinya adalah identik dengan beras yang layak dikonsumsi bagi pemenuhan makanan harian. Jika kurma menurut petunjuk hadits merupakan buah atau makanan yang penting sehingga bagi yang mengkonsumsinya perlu disediakan secara cukup dalam rangka memenuhi kebutuhan sehari hari, tentu bagi orang di luar wilayah Arab yang tidak menjadikan kurma sebagai makanan yang dikonsumsi sehari-hari, kurma layak dilihat penjelasannya terutama dari segi khasiatnya

\section{Syarah Hadis Buah Kurma untuk Susu Steril}

Syarah merupakan penjelasan tentang hadis, begitu pula syarah yang berkaitan dengan hadis merupakan usaha menafsirkan makna yang ada dibalik teks hadis (Darmalaksana, 2020c). Hadis yang bisa diamalkan ( $\left.m a^{\prime} m u l\right)$ berarti hadisnya telah diterima (maqbul) melalui takhrij (Darmalaksana, 2018). Berdasarkan takhrij menemukan status hadis riwayat Imam Muslim No. 3812 berkualitas shahih yang mana baik dari segi bersambung sanadnya, adil dan dhabit pula rawinya, dan dari segi matan tidak ada kejanggalan dan cacat.

Hadis riwayat Imam Muslim No. 3812 memberi keterangan bahwa hadits mengenai buah kurma itu selain bernilai shahih juga memberi petunjuk bahwa perlunya kesediaan buah kurma dalam setiap rumah atau keluarga untuk memenuhi stok makanan keseharian. Hadis ini juga memiliki hujah yang kuat dan memiliki nalar untuk menguak pemahaman hadisnya. Terlebih buah kurma berkhasiat sebagai anti pembekuan darah, anti imflamasi sehingga dapat menghilangkan rasa nyeri, kemudian dapat pula menyehatkan jantung dan yang paling penting dapat menjaga imun kita (Soebahar et al., 2015). Begitu juga dengan susu yang bermanfaat bagi semua kalangan masyarakat baik usia dini, remaja, sampai lanjut usia. Seperti kandungan protein dan mineralnya bisa dimanfaatkan bagi perkembangan dan pertumbuhan jaringan tubuh (usia dini), untuk mendukung berat badan yang sehat dan kesehatan gigi (remaja), dan untuk menjaga kesehatan jantung bahkan tulang (lanjut usia). Keduanya apabila disatukan antara kurma dan susu akan menghasilkan banyak sekali manfaat yang didapatkan (Fida, 2017).

Kurma diketahui sebagai buah yang memiliki keutamaan sebagai bahan olahan yang bermanfaat bagi kesehatan (Syamil, 2013). Buah kurma dapat diolah menjadi susu steril kurma bagi peningkatan imun di masa Covid-19. Meskipun demikian, hal ini membutuhkan eksperimen dengan melibatkan ahli bidang kesehatan. 
Jurnal Riset Agama, Volume 1, Nomor 1 (April 2021): 209-222

Asti Sovie Fuziawatie/Susu Steril Kurma Minuman Sehat untuk Masa Pandemi

Covid-19: Studi Takhrij dan Syarah Hadis Pendekatan Bidang Kesehatan

\section{Kesimpulan}

Kurma merupakan buah yang sangat tinggi nilai gizinya dan amat sesuai dengan tubuh badan manusia yang diciptakan Allah SWT. Manfaat kurma ditinjau dari sudut pandang medis menguatkan khabar Al-Qur'an Al-Karim dan Al-Sunnah Al-Shahihah tentang khasiat dan keutamaan kurma. Sebagian dari manfaat kurma, berfungsi untuk menguatkan sel-sel usus dan dapat membantu melancarkan saluran kencing karena mengandung serabut-serabut yang bertugas mengontrol laju gerak usus dan menguatkan rahim terutama ketika melahirkan. Fakta konsumsi susu di Indonesia juga antara lain menunjukkan bahwa konsumsi susu sapi segar di Indonesia termasuk paling rendah di Asia. Oleh sebab itu, perbanyak minum susu sapi yang kaya akan manfaat. Susu sapi segar yang dikasih kurma kemudian bisa dijus sampai haluspun manfaatnya tidak akan hilang. Maka dari itu, menjaga kesehatan dikala Covid-19 sangatlah penting dengan minum susu steril kurma bisa membantu imun kita. Penelitian ini diharapkan bermanfaat bagi masyarakat yang ingin mengetahui tentang susu steril kurma minuman sehat di masa pandemi Covid-19. Penelitian ini diharapkan dapat memberikan manfaat bagi informasi khalayak terutama yang ingin mengetahui takhrij hadis mengenai kurma. Penelitian ini memiliki keterbatasan hanya melakukan takhrij dan sayarah hadis tanpa melakukan kajian mendalam terkait dengan kesehatan, sehingga dibutuhkan penelitian lebih lanjut dari bidang ilmu kesehatan. Penelitian ini merekomendasikan agar adanya kolaborasi penelitian lebih lanjut antara peminat ilmu hadis dan ahli kesehatan untuk meneliti terkait manfaat buat kurma dan susu tersendiri dari segi medis.

\section{Daftar Pustaka}

Artha, J. (2021). Strategi Rasulullah dalam Menghadapi Wabah dan Implementasinya dalam Penanggulangan Pandemi Covid 19 (Studi Analisis Dalam Kitab Shahih Bukhari) (Vol. 19, Issue 080).

Christi, R. F., Edianingsih, P., \& Alhuur, K. R. G. (2019). Pentingnya Minum Susu untuk Anak Usia Dini, Remaja dan Lanjut Usia di Pesisir Pangandaran. Media Kontak Tani Ternak, 1(2), 12. https:/ / doi.org/10.24198/mktt.v1i2.23585

Darmalaksana, W. (2018). Paradigma Pemikiran Hadis. Paradigma Pemikiran Hadis, 466.

Darmalaksana, W. (2020a). Formula Penelitian Pengalaman Kelas Menulis. Jurnal Kelas Menulis UIN Sunan Gunung Djati Bandung, 2(1), 1-8. http://digilib.uinsgd.ac.id/32620/

Darmalaksana, W. (2020b). Metode Penelitian Kualitatif Studi Pustaka dan 
Jurnal Riset Agama, Volume 1, Nomor 1 (April 2021): 209-222

Asti Sovie Fuziawatie/Susu Steril Kurma Minuman Sehat untuk Masa Pandemi

Covid-19: Studi Takhrij dan Syarah Hadis Pendekatan Bidang Kesehatan

Studi Lapangan. Pre-Print Digital Library UIN Sunan Gunung Djati Bandung, 1-6. http://digilib.uinsgd.ac.id/32855/1/Metode Penelitian Kualitatif.pdf

Darmalaksana, W. (2020c). Penelitian Metode Syarah Hadis Pendekatan Kontemporer: Sebuah Panduan Skripsi, Tesis, dan Disertasi. Diroyah: Jurnal Studi Ilmu Hadis, 5(1), 58-68. https://doi.org/10.15575/diroyah.v5i1.9468

Darmalaksana, W. (2020d). Prosiding Proses Bisnis Validitas Hadis untuk Perancangan Aplikasi Metode Tahrij. Jurnal Ushuluddin UIN Sunan Gunung Djati Bandung, 1, 1-7.

Darmalaksana, W. (2021a). Herbal Tumbuhan Senna dalam Pengobatan Infeksi Covid-19: Studi Takhrij dan Syarah Hadis. 19, 1-11.

Darmalaksana, W. (2021b). Kosmetik Halal sebagai Lifestyle untuk Kesehatan: Stusi Takhrij dan Syarah Hadis. 148, 148-162.

Fida, A. (2017). Susu Hewan Ternak dalam Al-Qur'an Susu Hewan Ternak dalam Al-Qur'an (Kajian Tematik). 1.

Firdaus. (2015). Penelitian Persambungan Sanad Hadis. https:/ / doi.org/10.47435/al-qalam.v7i1.179

Irmayani, I., Bangun, S. M., Parinduri, A. I., \& Octavariny, R. (2021). Edukasi tentang Penerapan Protokol Kesehatan dalam Upaya Pencegahan Covid19. Jurnal Pengmas Kestra (Jpk), 1(1), 60-63. https:/ / doi.org/10.35451/jpk.v1i1.724

Nadhiran, H. (2014). Kritik Sanad Hadis: Telaah Metodologis. Jurnal Ilmu Agama UIN Raden Fatah, 15(1), 91-109.

Saleh, E. (2004). Dasar Pengolahan Susu dan Hasil Ikutan Ternak. 1-24.

Saltanera. (2015). Ensiklopedia Hadis Kitab 9 Imam. https:/ / play.google.com/store/apps/details?id=com.saltanera.hadits

Satuha, S. (2014). Hadis Kurma. In Universitas Islam Negri Sunan Djati Bandung.

Siti Rohmaturrosyidah Ratnawati, \& Ali Yasmanto. (2019). Studi Kritik Matan Hadis: Al-Bukhari: Jurnal Ilmu Hadis, 2(2), 209-231. https:/ / doi.org/10.32505/v2i2.1163

Soebahar, E., Daenuri, E., \& Firmansyah, A. (2015). Mengungkap Rahasia Buah Kurma dan Zaitun dari Petunjuk Hadis dan Penjelasan Sains. ULUL $\begin{array}{llll}A L B A B & \text { Jurnal Studi Islam, } & 19(2),\end{array}$ https:/ / doi.org/10.18860/ua.v16i2.3181

Syamil, A. (2013). Keistimewaan Kurma dalam Al-Qur'an Ditinjau dari Perspektif Ilmu Kesehatan, Skripsi.

Wardyaningrum, D. (2011). Tingkat Kognisi tentang Konsumsi Susu pada Ibu Peternak Sapi Perah Lembang Jawa Barat. Jurnal Al-Azhar Indonesia Seri 
Jurnal Riset Agama, Volume 1, Nomor 1 (April 2021): 209-222

Asti Sovie Fuziawatie/Susu Steril Kurma Minuman Sehat untuk Masa Pandemi Covid-19: Studi Takhrij dan Syarah Hadis Pendekatan Bidang Kesehatan

Pranata Sosial, 1(1), 19-26.

Yuliana, Y. (2020). Corona Virus Diseases (Covid-19): Sebuah Tinjauan Literatur. Wellness And Healthy Magazine, 2(1), 187-192. https:/ / doi.org/10.30604/well.95212020

Zulfadli. (2015). Kurma dalam AL-Qur'an (Kajian Tafsir Tahlili Terhadap QS Maryam/19:25-26). 
Jurnal Riset Agama, Volume 1, Nomor 1 (April 2021): 209-222

Asti Sovie Fuziawatie/Susu Steril Kurma Minuman Sehat untuk Masa Pandemi Covid-19: Studi Takhrij dan Syarah Hadis Pendekatan Bidang Kesehatan

Halaman ini sengaja dikosongkan 